\title{
THE REPRESENTATION OF POWER AND DOMINATION IN ASSASSIN'S CREED: A MULTIMODAL CRITICAL DISCOURSE ANALYSIS
}

\author{
Clerensia Tian Sunarto \\ Jember University \\ clerensiatians@gmail.com \\ Albert Tallapessy \\ Jember University \\ Albert@unej.ac.id \\ Sabta Diana \\ Jember University \\ sabtadiana@gmail.com
}

\begin{abstract}
This study aims to reveal the power of dominant group which is from different social class and status. The data source is a movie entitled Assassin's Creed which is downloaded from internet. The theory of Generic Structure is used to identify the elements of the movie and to collect the data. The data are analysed in the form of shots and clauses which is visual and linguistics element. The linguistics data are analysed by using Systemic Functional Linguistics (SFL) by Halliday (2004) the other hand, the visual data are analysed by using Systemic Functional Visual Element by Kress and Van Leeuwen (2006). Therefore, this research is Critical Discourse analysis (CDA) study. The research's finding is the power that represents by the dominant people which is constructed in Assassin's Creed.
\end{abstract}

Keywords: Systemic Functional Linguistic, Systemic Functional Visual Element, Critical Discourse Analysis, Domination.

\begin{abstract}
ABSTRAK
Penelitian ini bertujuan untuk mengungkap kekuatan kelompok dominan yang berasal dari kelas dan status sosial yang berbeda. Sumber data adalah film berjudul Assassin's Creed yang diunduh dari internet. Teori Struktur Generik digunakan untuk mengidentifikasi elemen-elemen film dan untuk mengumpulkan data. Data dianalisis dalam bentuk shot dan klausa yang merupakan elemen visual dan linguistik. Data linguistik dianalisis dengan menggunakan Sistemik Fungsional Linguistik (SFL) oleh Halliday (2004) Di sisi lain, data visual dianalisis dengan menggunakan Sistemik Elemen Visual Fungsional oleh Kress dan Van Leeuwen (2006). Oleh karena itu, penelitian ini adalah penelitian Analisis Wacana Kritis (CDA). Temuan penelitian ini adalah kekuasaan yang diwakili oleh orang-orang dominan yang terjadi di Assassin's Creed.
\end{abstract}

Kata Kunci: Sistemik Funsional Linguistik, Sistemik Fungsional Elemen Visual, Analisis Wacana Kritis, Dominasi. 


\section{INTRODUCTION}

The study of discourse has recently become popular among intellectuals across disciplines, both in linguistic science, sociology, psychology, cultural studies, and others. Initiated from linguistic studies, the development of this interdisciplinary discourse in turn resulted in a variety of concepts and meanings of these discourses because of the different perspectives of each of these disciplines. In fact, as scientific developments change dynamically, the concept of discourse in a scientific discipline also develops and varies. The weakness of the conception of discourse developed by previous thinkers was criticized and reconstructed by other thinkers. This results in the conceptualization of discourse that never ends.

The development and reconstruction of the concept of this discourse, for example, is exemplified by Michel Foucault, who was initially motivated by his anxiety about reducing the meaning of discourse (discourse) (Mills, 2001: 6). Based on his criticism of Ferdinand de Saussure's structuralism, which regards language as a system of meaning production which is strictly composed of signified and signifier, Foucault on the contrary asserts that language (discourse) is a system of meaning production that provides individuals how to see, think, and signify behave. In this sense, the discursive practice of individuals is seen as the effect of discourse which is basically quite related to power relations.

Foucault's conception on the one hand made an important contribution in the shift of the language paradigm from structuralism to post-structuralism, but on the other hand his thoughts that radicalized discourse, power, history, subjects, ratios, etc. reaped many critics who regarded him as anti social change, pro -relativism, anti-epistemology, antisubject, irrational, traditional (rather than postmodern), etc. Jurgen Habermas, for example, considers Foucault's position based on traditional rather than postmodern perspectives, related to his criticism of modernity which has lost 'normative notion' which has become the basis for criticizing him in the traditional perspective rather than postmodern, related to his criticism of modernity that loses 'normative notion' . In general, Habermas calls Foucaults a supporter of 'presentism, relativism, and kryptonhargavism' as a result of their destruction of the 'truth' and their rejection of the ratio through the ratio itself (Hardiman, 2009:249)

Power is not always done by a person. Sometimes it is represented by a group of people which is organization or an institution. They can control other people in a society. People are living in a society which is grouped by their social class of people in a particular environment. Nowadays, it is quite rare for a person who lives individually without any favour or communication with the others. Human uses 
language to make a communication. Sometimes people do not realize that they were under control which happened in our daily communications. Fairclough (1989:20) stated that, "Language is the part of social practice". In this kind of communication, it is found in differences social class. One of the differences is about power and domination. This power is the part of Discourse and it happens in the scope of group, institution and organisation (Van Dijk, 2005:354). Power in a specific group or institution are usually distributed to a special social domain, such as politics, the media, law and order, education or corporate business, and thus have a different centres of power and elite group that control such centres. This could be seen from the way they communicate by a verbal language. These are the part of Critical Discourse Analysis (CDA), which is an approach of linguistic study. Critical Discourse Analysis is a critical analysis of phenomenon that happened in a language uses which is spoken or textual language which addresses social problems (Fairclough and Wodak, 1997:271-81). This approach brings us into a more critical way of thinking towards the use of our language in our social life as a tool of human communication.

According to Fairclough (1989:44), Power in Discourse appeared between unequal participants or unequal encounter. He determined several devices of language manipulation and control's model such as, instruction, evaluation the other participant's verbal behaviour, questions, interruption, explicitness, controlling topic, reformulation, and repetition. All of these devices are the representation of Power in Discourse. Furthermore, Language and power have an impact to their society. Basically, Critical Discourse Analysis (CDA) is a critical thinking about language phenomenon. CDA is highly interested in doing linguistic textual analysis of the use of language in social interaction. This character also distinguishes CDA from other theories such as Laclau and Mouffe and discursive psychology which is more concise in rhetorical analysis and does not involve systematic linguistic analysis of social language use (Jorgensen \& Phillips 2002). Language is not only just a tool to represent several one's powers, but also gives an impact towards their interlocutor, moreover their society which is Domination. Power and Domination are two unrelated things. Based on Van Dijk (2005:355), Power is an ability to control over the others acts or mind that have no power or powerless. The more powerful side is expressed to be more dominant. Power and domination are considered legal and occur naturally. This statement cannot be rejected, because it is several things that can be achieved and owned by anyone, which has the same opportunity.

There are several power resources such as, force, money, status, fame, knowledge, information, and "culture". Fairclough (1989:63) used religious rituals as 
illustration constraints on access in discourse, that no one could officiate a church service if you are not a priest; furthermore there is a rather rigorous process of selection. Nowadays, religion became the most popular tool to exercised power toward society. These people used their group's identity to get other people attentions. Moreover, they did violence and terrorism in the name of religion. This is also one of many ways to get power and domination by force and religion identity. This kind of discourse also represented in the chosen movie of researcher entitled Assassin's Creed. The movie is about a conflict between two groups that have a different view about freedom of life. They are the Assassin's and the Templar's. They are fighting for an "Apple" that consists of knowledge. They are belief that the one who own the "Apple" will own the world too.

Nowadays, power and domination could be illustrated through various aspects of human life. One of the real facts that most of people use religiosity to take control of people who dominated in the particular society and these phenomena is happening now. It happened in the scope of politics. Their purpose is to get one of the chairs in government so that they can take control over the society. The researcher saw similar phenomena represent on Assassin's Creed movie. This is the researcher's reason to choose this movie. While, the most effective ways to illustrate is a media discourse and use language as a tool to convey a message. It is contains of scenes, acts, and language to illustrate a power and dominations which is understandable easier. Therefore, movie is chosen as a main data of this analysis.

The title of the chosen movie is Assassin's Creed and released in 2016. This movie based on a video game by Ubisoft. It is an American action adventure film directed by Justin Kurzel and written by Michael Lesslie, Adam Cooper and Bill Collage. Assassin's Creed movie main stars are Michael Fassbender as Callum Lynch and Aguilar de Nerha (Assassin), Marion Cotillard as Sophia Rikin and Jeremy Jhon Irons as Alan Rikin (Templar). According to IMDb by Col Needham (https://www.imdb.com/title/tt2094766/,2016), this movie reaches 5,8 rating from scale 1-10 which is given by the viewers of this movie. The movie line story features an original story and mythology series' expands. The director said that there will be a sequel movie to explore more about Assassin's Creed.

There is an interesting mythology about the movie story which is about power and domination between two different social classes. The issue represents through language in movie's characters conversation and images of the Assassin's Creed movie. The movie will be analyzing used Systemic Functional Linguistics (SFL) theory by Halliday (1997). This theory will help researcher to examine the types of 
language and power based on the process, interaction and mode in chosen conversation of the subtitle. This analysis is about criticising the meaning of the movie, therefore Critical Discourse Analysis (CDA) by Fairclough (1995) is used to reveal the powerful group between Assassins and Templar. Multimodality is also used to analyse the movie scene that consists of the sign. Others supporting theories are Language and Power by Fairclough (1989), Generic Structure (GS) by Halliday and Hasan (1985), and Systemic Functional Multimodal Discourse Analysis (SF MDA) by Kress and Leeuwen (2006).

\section{THEORY AND METHOD}

According to Halliday and Hasan (1989), General Structure, to be short after here GS, is a structure that built up together within the text and it's refer to a global message. The structure of a text has a strong relation with a context. Through a context we can find out the structure that is used in a particular text. Hasan (1985) provided five the notions of Contextual Configuration, these are; what elements must occur, what elements can occur, where must they occur, where can they occur, how often can they occur. It is possible to know the structure of a text by using the Contextual configuration. The possibilities are obligatory elements, optional elements, the sequence and the interaction of text.

The second theoretical frameworks is Systemic Functional Linguistic (SFL). According to Halliday (2004), the definition of SFL focuses on the language functions as well as the name. It is a tool to analyse the language structure as a function by detecting the system that is used in each sentences of a text. The main focus of this theory is stratification which consists of four strata; there are context, semantics, lexico-grammar and phonology-graphology. Halliday divided context in to two types. The first is context of culture and the second is context of situation. Language used in every kind of situation in our life. This statement makes the theory of context strongest, because it aims to figure out the semantic of a language in a particular text. According to the meaning, language has a different perspective toward the listener. Halliday believed that this perspective can be controlled by a system. SFL is divided into three components which are called as metafunction. The researcher only uses two metafunctions to analyse the data on this research. They are ideational metafunction which is transitivity system and the second is interpersonal metafunction.

The next is Multimodality which is a study of discourse that analyze a language phenomena which combined with other several resources as a communication and representation of visual semiotic (Krees and Van Leeuwen, 
2006:1).They are images, gesture, action, sounds and music. This multimodality theoretical helps people to define more meaning of a written text. It is sometimes difficult to show the real meaning of a written text. While, image is a visual elements which explained more detail. All of those elements are the part of a movie. This theoretical continued with Systemic Functional Visual Element by Kress and Van Leeuwen (2006). This is a theory for Multimodal Discourse Analysis because it is a social semiotic theory to find the meaning of a context (Halliday, 1978). There are three metafunctions which is extended to visual social resources to figure out the semiotic modes' meaning. This theory use three different process of meaning. There are Ideational Metafunction, Interpersonal Metafunction and Textual Metafunction. Since the analysis is a Critical Discourse Analysis, the theoretical of CDA used Faisclough's "Three-dimensional” framework.

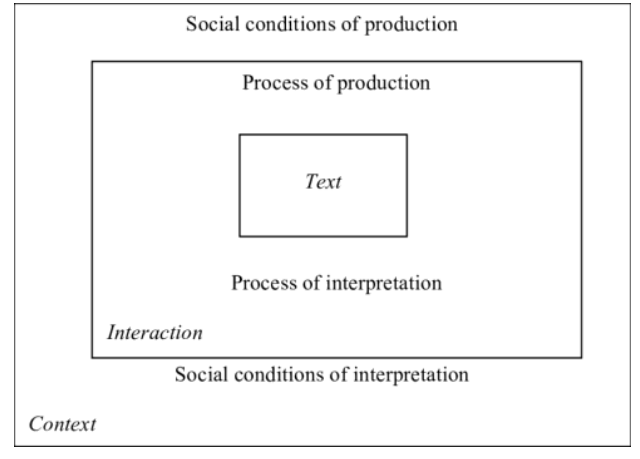

Diagram 1: Dimension of Discourse

The first stage is the text analysis that analysed the contruction of the text as a process of production. The second stage is the process of interpretation which is the interaction between the text and the situation of context, the last stage is the social condition of production which is concerned with the relationship between the interaction and social context. Language and power is also used as the theoretical framework. According to Fairclough (1989:43), it focused on two major aspects connected to language and power; there are power in discourse and power behind discourse. Power in discourse sub-topics are power in 'face-to-face' spoken discourse, power in 'cross-cultural' discourse where the participants belong to different ethnic groupings and the 'hidden power' of the discourse of the mass media. Power behind discourse is a power that has an unknown effect of power. This research focuses on the face-to-face spoken discourse because the participants are the unequal encounter. The more powerful group control the powerless group in a particular discourse. The indicator of the powerful group is on their utterances. Power is a concept beneath someone's mind and it comes out because of position unequally that can be identify on the impact of utterance that uses by an individual to others. There are two categorized of power, there are power in discourse and 
power behind discourse (Fairclough, 1989:43). It means that the existence of power in society could be felt or not. This theory also used in analysing the real power owner in Assassin's Creed movie.

The type of this research is qualitative which the data types must a word or visual images. This research uses Critical Discourse Analysis (CDA) by Fairclough (1989) as the approach to reveal the power and domination which is represented in this movie. It is a study of a text that is believed to have a meaning beyond the text itself. The meaning can be found by analysing the text used three dimensional of Fairclough. They are description, interpretation, and explanation. It helps the researcher to reveal the power and domination in the movie. This research used a movie entitled Assassin's Creed (2016) as a data source. The movie duration is 115 minutes. This movie downloaded in https://grandxxi.com/assassins-creed2016/play/ $\mathrm{ep}=2 \& \mathrm{sv}=1$. The movie dialog and visual images are used as data. The visual data were taken by watching the movie and screen captured the chosen shoots by using KMPlayer. Furthermore, while watching the movie, the researcher was also transcribing the whole dialog in the form of written script. The sentences and shots were selected by using Generic Structure (GS) by Halliday and Hasan (1989). There were 36 clauses and 43 shots which relevant with the issue. The elements of Assassin's Creed are found by using Generic Structure by Halliday and Hasan. The Generic Structure's formula can be seen as follow:

Table 1. The formula of generic structure in Assassin's Creed

\section{$\mathrm{EX}^{\wedge} \mathrm{CO}^{\wedge} \mathrm{CX}^{\wedge} \mathrm{FA} A^{\wedge} \mathrm{R}$}

Each symbol can be identified as follow:

Table 2. the explanation of the elements of generic structure in Assassin's Creed

\begin{tabular}{lll}
\hline GS: Generic Structure & CO: Conflict & FA: Falling Action \\
\hline EX: Exposition & CX: Climax & R: Resolution \\
\hline
\end{tabular}

Eventual, the elements were found and the data were chosen from each element based on the data which has an issue of power and domination in the movie. There were 8 data which consist of 43 shots and 37 clauses. Here, the recapitulation of the data as follows: 
Clerensia Tian Sunarto, Albert Tallapessy, Sabta Diana - Representation of Power and Domination in Assassin's Creed: A Multimodal Critical Discourse Analysis

Table 3. Total Shots and clauses

\begin{tabular}{lcc}
\hline \multicolumn{1}{c}{ Scene } & Shots & Clauses \\
\hline Callum Lynch's house scene & 3 & 6 \\
\hline Village of Spain scene & 12 & 4 \\
\hline Abstergo Lab scene & 4 & 7 \\
\hline Room of Patient scene & 5 & 6 \\
\hline Sultan Muhammad's Kingdom scene & 3 & 4 \\
\hline Grand Templar Hall scene & 3 & 4 \\
\hline The death of Allan Rikkin scene & 3 & 3 \\
\hline Templar oath scene & 1 & 2 \\
\hline Total shots and clauses & 43 & 37 \\
\hline
\end{tabular}

\section{FINDING AND DISCUSSION}

Assassin's Creed speaks about power that is done by the dominant group who has more members, facilities, connection and higher status to control over powerless poeple who has no status. The power could be exercise through violence, status, money and etc. Those issues are being the focus of the analysis through the selecte scenes.

\section{A. Unequal Encounter}

This scene is taken from Exposition element. It represents the unequal encounter between Templar and the villagers.

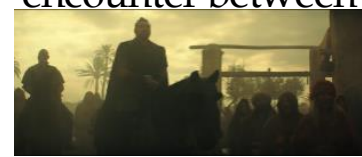

(1)

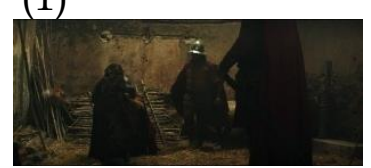

(5)

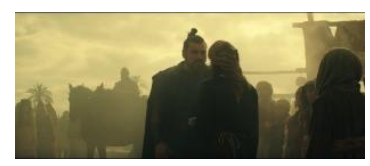

(9)

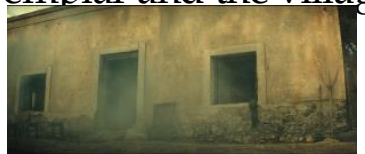

(2)

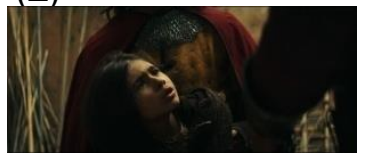

(6)

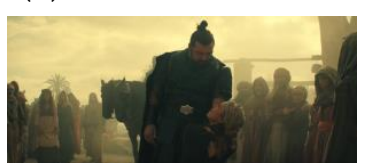

(10)

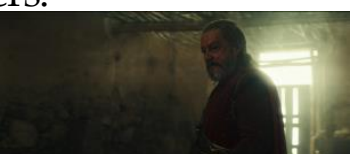

(3)

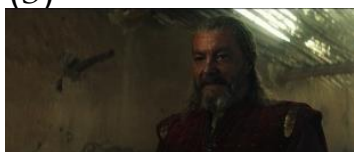

(7)

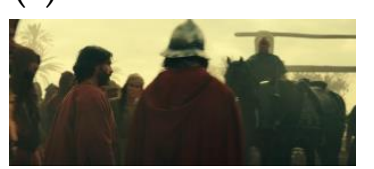

(11)

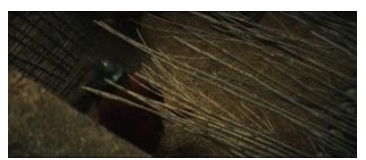

(4)

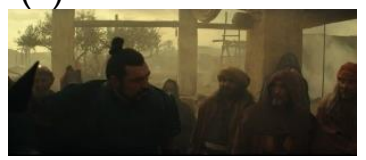

(8)

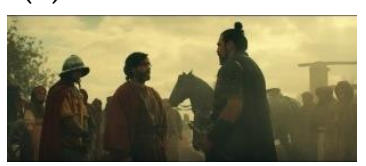

(12)

Figure 1. Shots of Village Scene

This scene shows movie setting of Spain in 1492. The context of situation of this image shows that Templar is looking for Prince Granada that kept in one of 
village and finally found the Prince. The General of the Templar knight get into a house to take the Prince with them, while one of the Templar's army, Ojeda is asking one of the villagers about the family who kept the Prince. This situation shows that the other villager are afraid of them and just keep silent while a women is tortured by Ojeda. The visual and linguistics elements analysis are elaborated in the table below.

Table 4. the result of the analysis of visual elements of Village scene

\begin{tabular}{|c|c|c|c|}
\hline \multirow{4}{*}{$\begin{array}{l}\text { Ideational } \\
\text { Meaning }\end{array}$} & \multirow{2}{*}{ Participants } & Actor & Ojeda \\
\hline & & Goal & Villager \\
\hline & Process & Narrative & Action \\
\hline & Circumstance & Locative & Foreground \\
\hline \multirow{8}{*}{$\begin{array}{l}\text { Interpersonal } \\
\text { Meaning }\end{array}$} & \multirow{2}{*}{ Camera Movement } & Camera Panning & $\begin{array}{l}5 \text { Shots in } \\
(1),(3),(8),(9),(11)\end{array}$ \\
\hline & & Camera Stationary & $\begin{array}{l}7 \text { shots in } \\
(2),(4),(5),(6),(7),(10),(12)\end{array}$ \\
\hline & Image Act & Offer & \\
\hline & \multirow{3}{*}{ Size of Frame } & Close Shot & 2 shots in $(6),(7)$ \\
\hline & & Medium Shot & $\begin{array}{l}6 \text { shots in } \\
(3),(8),(9),(10),(11),(12)\end{array}$ \\
\hline & & Long Shot & 3 shots in $(1),(4),(5)$ \\
\hline & Distance & Public Distance & 12 shot \\
\hline & Colour & Low Saturation & \\
\hline \multirow{3}{*}{$\begin{array}{l}\text { Textual } \\
\text { Meaning }\end{array}$} & \multirow{2}{*}{ Information Value } & Left & Ojeda \\
\hline & & Right & Villager \\
\hline & Salience & Ojeda & \\
\hline
\end{tabular}

Based on Table 4, the process is the narrative actional process of Ojeda as the Actor and the Villager as the Goal which is the ideational structure the circumstance is locative because there is other object in the foreground that has softer focus than the main object. The foreground is the villagers who seen Ojeda torture the woman. It also can be seen by Ojeda statement after he knew about the family who harboured the Prince as can seen below.

Ojeda: | | hang his family and make him watch | | 
Clerensia Tian Sunarto, Albert Tallapessy, Sabta Diana - Representation of Power and Domination in

Assassin's Creed: A Multimodal Critical Discourse Analysis

Table 5. The Analysis of Clause 11 in Village of Spain scene

\begin{tabular}{llll}
\hline (You) & Hang & His family & And make him watch \\
\hline Actor & Process: Material & Goal & Client \\
\hline & Finite & Predicator & \\
\hline Mood: Declarative & & Residue \\
\hline
\end{tabular}

This scene represents the power behind the lower class people. It is a conversation between Templar who have status and power behind the villagers who have no power againts them because the power in discourse in type of 'face-to-face' discourse can be seen from the unequal encounter (Fairclough, 1989:44).

\section{B. Power in Domination}

This Sscene is taken from the Conflict element. It represents the power in domination.

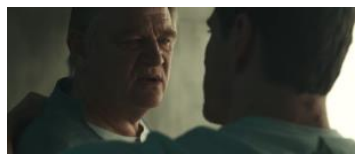

(1)

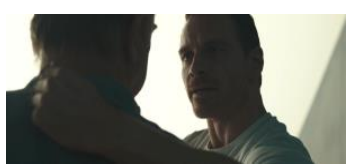

(4)

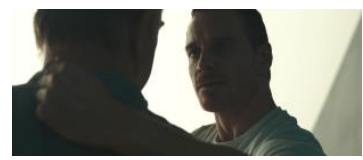

(2)

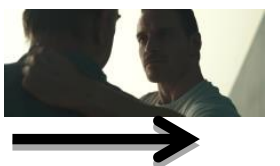

(3)

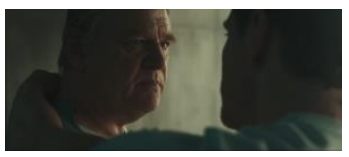

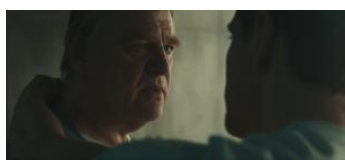

(5)

Figure 2. Shots of Patient's Room in Abstergo scene

This scene is taken from conflict element. The context of situation of this shot shows that Callum and his father talking about the Abstergo purpose. This conversation happened after Allan manipulated Call about his purpose in Abstergo. Allan knows that Call's father killed her mother many 30 years ago. He used this background story to manipulate and trigger his emotional to make a deal with Allan. In this image, Joseph tries to explain what Templar wants to do to Call and all the Assassin's descendants. Callum wants revenge to his father because of his mother's death. The analysis of visual and linguistics elements are explained and interpreted below. 
Table 6. the result of the analysis of visual elements of Patient's room scene

\begin{tabular}{|c|c|c|c|}
\hline \multirow{4}{*}{$\begin{array}{l}\text { Ideational } \\
\text { Meaning }\end{array}$} & \multirow{2}{*}{ Participants } & Actor & Joseph \\
\hline & & Goal & Callum \\
\hline & Process & Narrative & Reactional \\
\hline & Circumstance & Means & Joseph and Callum \\
\hline \multirow{7}{*}{$\begin{array}{l}\text { Interpersonal } \\
\text { Meaning }\end{array}$} & Camera Movement & Camera Stationary & 5 shots \\
\hline & Image Act & Offer & \\
\hline & \multirow{3}{*}{ Size of Frame } & Close Shot & 5 shot \\
\hline & & Medium Shot & - \\
\hline & & Long Shot & - \\
\hline & Distance & Close Personal & 5 shots \\
\hline & Colour & Low Saturation & \\
\hline \multirow{3}{*}{$\begin{array}{l}\text { Textual } \\
\text { Meaning }\end{array}$} & \multirow{2}{*}{ Information Value } & Left & Joseph and Callum \\
\hline & & Right & - \\
\hline & Salience & - & \\
\hline
\end{tabular}

Table 6 shows that Joseph is the actor and Callum as the goal. The ideational structure shows the narrative reactional process because Callum and his father doing a conversation that formed a vector which is an eye-line, by the direction of the glance of one or more of the represented participants (Kress and Van Leeuwen, 2006:67). The shots show that Callum and Joseph doing a deep conversation as deep as their glance. The circumstance is means of a process is formed by the tool with the Actor which the action is executed (Kress and Van Leeuwen, 2006:75). The power in domination also can be seen from the statement from the characters.

| | The Apple contains the genetic code for free will | |

Table 7 The Analysis of Clause 23 in Room of Patient Scene

\begin{tabular}{lll}
\hline The Apple & $\begin{array}{l}\text { Contains The } \\
\text { genetic code }\end{array}$ & For free will \\
\hline & Process: Material & Circumstance \\
\hline Subject & Finite & \\
\hline Mood: Declarative & Residue & \\
\hline
\end{tabular}

| | They will use it to destroy us | | 
Table 8 The Analysis of Clause 24 in Room of Patient Scene

\begin{tabular}{|c|c|c|c|}
\hline They & will use & It & to destroy us \\
\hline Actor & Process: Material & Circumstance & Goal \\
\hline Subject & Predica & tor & \\
\hline $\begin{array}{l}\text { Mood: } \\
\text { Declarative }\end{array}$ & Residue & & \\
\hline
\end{tabular}

Based on Table 7-8, Joseph explain the reason behind his statement by this utterance, The Apple contains the genetic code for free will. The Apple (artefact) as the Subject and the genetic code as the Goal. Further, Allan's purpose is also explain by Joseph as his last utterance in this scene, they will use it to destroy us. They (templar) as the Actor and to destroy us as the Goal. It means that Templar have more armys and member and also something powerfull to destroy Assassin's that have been killed and caught by Templar.

\section{Social Analysis : The socio-cultural context and Power Domination Discourse in Assassin's Creed}

After the description and interpretation explained above, this subchapter discussed the explanation of the interpretation by elaborating it with socio-cultural context related to the power and domination issue in Assassin's Creed movie.

The movie presents the historical background of fight over Apple Eden by Templar and Assassin with the aim for a better future of the world. This war happened for centuries which are a seizure of territory and power in the Mediterranean region to European countries. It is known that in the real world that nowadays, people on behalf of religion to gain their interests with reasons to change the world into a better future. This representation inspired by real historical story. Based on Templar historical story, this war is called as Crusade to take over the Holy Land from Muslim rule. Templar beliefs that the world will be a better place under the control of Templar rule. They also have other purposes which are suppression of paganism or political and territorial advantage.

This kind of representation inspired by real issue in the world is also showed through two different movie setting of location, time and the characters of the movie. The first movie setting is in Spain, 1492 and the characters are the Templar and Sultan Muhammad. For centuries, the Order of Knight Templar has searched for the mythical Apple of Eden. They believe it contains not only the seeds of man's first disobedience, but the key to free will itself. If they find the relic and decode its 
secrets, they will have the power to control all freedom of thought. But, there is a brotherhood that stands in their way. This brotherhood called the Assassins. This story begins in Andalucía, Spain 1492 where the Assassins brotherhood takes an oath to protect the free will from Templar army. They believe that if the Apple falls into Templar hands, they will destroy protest, dissent, and our right to think. Afterwards, Templar is searching and arresting Prince Granada as their captive. They want to take the Apple Eden from Sultan Muhammad by exchange with the captive as showed in Kingdom of Sultan Muhammad scene (see appendix 1 table S5 page 59). Templar was constraining the contribution of Sultan Muhammad which has no choice to safe his son.

Based on the real world history, it is said that the final chapter of the Crusade by Knight Templar begun in 1095 called as the First Crusade. Paus Urbanus II happened in Granada, Spain in 1492. Besides, the story is different from the movie. It is told that Granada won over Templar because of the deterioration of the Europeans during the reign of Christians rule. This became the sign that the Crusade is over. It is also told that the idea of Crusading continued until the end of the 18thcentury but focused of Western European became more interest to the New World.

Besides, the movie represents a different story in the second time setting. The modern era of European is represented through Allan Rikkin and Sophia Rikkin as the Templar. While, The Assassins represented by Joseph Lynch and Callum Lynch. It is prove their identity as Templar and Assassins are flowing in their blood as show in the first scene by Joseph Lynch. He said that, your blood is not your own blood (see appendix 2 table 2 page 62). He tried to say that Callum is the descendants of Assassins which means that Callum has to protect the Apple Eden from Templar. Callum is son of Joseph who is and Assassins who ran away from Allan Rikkin as the representation of Templar in the new era. Callum is about 12 years old when his father told him about the Assassins identity. He saw her father killed her mother because the situation here was the same as the first movie setting. Allan wants to take Callum as captive because he is the right descendant who knows the existence of Apple Eden. Afterwards, Joseph said, they found us. Live in the shadows Go! Go now! (See appendix 2 table 3-6 page 62). 30 years later, Sophia Rikkin found Callum in the day of his death penalty. She brought Callum to the Abstergo where the Anymous place. The movie describes the Anymous as the machine which synchronize the object with the DNA of its ancestor. Callum was forced to undergo a synchronization process with his ancestral memory. Allan said, He has to go back in the Animus, Now (see appendix 2 table 8 page 64), but her daughter will not push 
Call because of his healthy and risk his life, He needs more time (see appendix 2 table 9 page 64). Allan is also constraining the contributions of Sophia and Callum.

The representation of power in domination between unequal encounter are seen in the movie and it has been proven in the analysis of visual and linguistics elements in the previous sub chapters. By the result of linguistic and visual elements, it is showed that the assumption of power and domination are contracted by the movie. Further, the movie also speaks critically about the issue that was happened in the world which is in the previous centuries especially in the issue politics.

\section{CONCLUSION}

Related to the results and discussion, The conclusion discussed the final answer of the research question; The visual and linguistic elements showed in the movie, The interplay between visual and linguistic elements of the movie which indicates power and domination discourse, The socio-cultural context of the movie which represents the power and domination discourse.

The shots and the utterances showed in the selected data represent the power and domination by the characters of the movie. Here, the data mostly show the characters have the dominant behaviour caused by many several factors. The data also show how the power exercised between the dominant group and the minority group of people. Next is the interplay between visual and linguistics element constructed the assumption of power from Templar as the dominant side by the interaction between visual and linguistic elements. The visual elements analyzed with three dimensions of meaning, ideational, interpersonal and textual. For example in the first scene, Callum Lynch's house scene, the character is showed as the minority people through the size of frame and the distance which is coherence with the utterances said by the characters that show their fear of Templar which is know as the dominant people from their behaviour. After the analysis of visual and linguistic element, the socio-cultural context is used to explain and prove the representation of power and domination together with the theory of Language and Power which is under the Critical Discourse Anlaysis (CDA) study. These elements are social practice connected to the existence of power domination in this movie. The background of the movie is inspired from the real historical story from The Knight Templar in 1492. It was the war between The Knight Templar againts the people of Granada which has a population of Islamic religion. This history begun with the spread of Catholicism to various European countris, then over time, Templar abuse power by looted goods and committed violence in order to get territory. However, as the findings sugest, the representation of power and domination shows Templar 
as the dominant group who has more power above the Assassin's. It means that Templar has more army, network and supporting facilities

\section{REFERENCES}

Denscombe, M. 2007. The Good Research Guide: for small-scale social research projects. 3rd ed. Open University Press.

Van Dijk, T. A. 2005. Discourse and Power in a Multilingual World. Jhon Benjamins Publishing.

Van Dijk, T. A. 2015. The Handbook of Discourse Analysis. Edited by John Wiley \& Sons

Fairclough, N. 1989. Language and Power .Routledge.

Fairclough, N. 1995. Critical Discourse Analysis : The Critical Study of Language. Longman. London and New York

Halliday, M.A.K. and Hasan, R 1985. Interpersonal Rhetoric in the Editorials of China Daily: A generic Perspective. Peter Lang.

Halliday, M.A.K. 1997. An Introduction to Halliday's Systemic Functional Linguistics. Journal for the Study of English Linguistics

Halliday, M.A.K. 2009. Complementary Between Leis and Grammar in the Systemn of Person: Asystemic Typological Approach. Taylor \& Francis.

Halliday, M.A.K. 2014. An Introduction to Functional Grammar. Revised by Christian M.I.M. Mathiessen.

Hardiman, F. Budi. (2009). Menuju Masyarakat Komunikatif. Yogyakarta: Kanisius.

Janah, Rohdatul. 2017. A study on Power and Dominance of the main character Grey in Fifty Shade of Grey Movie: A Multimodal Critical Discourse Analysis. English Department. Jember University. Unpublished.

Jorgensen, M. and Phillips, L. (2002). Discourse Analysis as Theory and Method. Los Angeles: Sage.

Kress, G. 2001. The Future of Literary Sttudies. M. Baynham, M. Prinsloo Springer.

Kress, G., and Leeuwen,T.V.2006. Reading Images: The grammar of Visual Design. Routledge.

Mills, Sara. (2001). Discourse. New York \& London: Routledge.

O'Halloran, K.L .2011. Multimodal Discourse Analysis. In press.

Rajala, E. 2018. "We don't need anyone to tell us what to do".The Power Relations in Assassin's Creed II. Department of Language and Communication Studies.University of Jyväkylä. 
Clerensia Tian Sunarto, Albert Tallapessy, Sabta Diana - Representation of Power and Domination in Assassin's Creed: A Multimodal Critical Discourse Analysis

Tobing, O.R. 2013. A Critical Discourse Analysis of 8 Mile Movie. Universitas Kristen Satya Wacana.

Weber, M. 2017. Max Weber and International Relations. Edited by Richard Ned Lebow. 